\title{
Water-pipe smoking promotes epithelial- mesenchymal transition and invasion of human breast cancer cells via ERK1/ERK2 pathways
}

\author{
Khaled W. Sadek ${ }^{1,2 \dagger}$, Mahmoud Y. Haikk ${ }^{1,2 \dagger}$, Anas A. Ashour ${ }^{1,2 \dagger}$, Tahira Baloch ${ }^{3}$, Tahar Aboulkassim³, \\ Amber Yasmeen ${ }^{3}$, Semir Vranic ${ }^{1 *} \mathbb{D}$, Asad Zeidan ${ }^{1}$ and Ala-Eddin Al Moustafa 1,2,4,5*
}

\begin{abstract}
Background: With the increasing popularity of water-pipe smoking (WPS), it is critical to comprehend how WPS may affect women's health. The main goal of this study is to identify the potential outcome of WPS on human breast cancer progression.

Methods: Two breast cancer cell lines, MCF7 and BT20, were used in this investigation. We explored the outcome of WPS on cell morphology and cell invasion using inverted microscope and Biocoat Matrigel invasion chambers. On the other hand, Western blot was employed to study the expression patterns of key control genes of cell adhesion and invasion.

Results: Our data reveal that WPS induces epithelial-mesenchymal transition (EMT) of MCF7 and BT20 breast cancer cell lines; thus, WPS enhances cell invasion ability of both cell lines in comparison with their matched controls. More significantly, WPS provokes a down- and up-regulation of E-cadherin and focal adhesion kinase (FAK), respectively, which are important key regulators of cancer progression genes. Finally, our data point out that WPS incites the activation of Erk1/Erk2, which could be behind the stimulation of EMT and invasion as well as the deregulation of E-cadherin and FAK expression.

Conclusion: Our data show, for the first time, that WPS initiates EMT and stimulates cell invasion of breast cancer cells, which could incite metastatic development in breast cancer patients. Thus, we believe that further studies, both in vitro and in vivo, are required to elucidate the pathogenic outcome of WPS on cancer progression of several human carcinomas including breast.
\end{abstract}

Keywords: Water-pipe smoking, Breast cancer, EMT, Cell invasion, Cell adhesion, Erk1/Erk2 pathways

\section{Background}

Tobacco smoking, although easily preventable, is considered a major cause of morbidity and mortality worldwide, accounting for 6 million deaths each year (World Health Organization). Tobacco smoking today has different forms including cigarette, cigar smoking, e-cigarettes as well as water pipe. Indeed, water-pipe

\footnotetext{
*Correspondence: semir.vranic@gmail.com; ala-eddin.almoustafa@mcgill. ca; aalmoustafa@qu.edu.qa

${ }^{\dagger}$ Khaled W. Sadek, Mahmoud Y. Haik and Anas A. Ashour contributed equally to this work

${ }^{1}$ College of Medicine, Qatar University, Doha, Qatar

Full list of author information is available at the end of the article
}

smoking (WPS) is the most common tobacco use in the Middle-East region, and its popularity around the globe is rapidly increasing to the extent that WPS has been described as a global epidemic [1]. Water pipe provides a variety of flower-flavored tobacco in addition to various spices and fruits with some regional and cultural differences [2]. Common misconceptions that consider WPS less harmful than cigarettes exist, which have been pointed out in several studies [2, 3]. Nevertheless, earlier investigations reported the obvious harmful effects of WPS on human health, which are comparable, and maybe even worse, than that of cigarette smoking [4-6]. Thus, meta-analysis reports clearly indicate

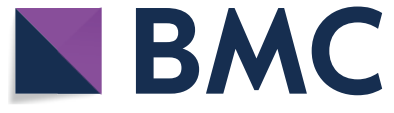

(c) The Author(s) 2018. This article is distributed under the terms of the Creative Commons Attribution 4.0 International License (http://creativecommons.org/licenses/by/4.0/), which permits unrestricted use, distribution, and reproduction in any medium, provided you give appropriate credit to the original author(s) and the source, provide a link to the Creative Commons license, and indicate if changes were made. The Creative Commons Public Domain Dedication waiver (http://creativecommons.org/ publicdomain/zero/1.0/) applies to the data made available in this article, unless otherwise stated. 
positive associations between WPS and chronic diseases such as lung, esophageal and bladder cancer, respiratory illness, low birth weight and periodontal diseases $[7,8]$. On the other hand, passive smoke from WPS can also cause serious risk of respiratory diseases as well as other health disorders and possibly cancers in exposed nonsmokers [9-11].

To date, it has been well established that cigarette smoking can have multiple adverse effects on human health including cardiovascular and lung diseases as well as several types of cancers such as breast [12-15]. For instance, recent investigations have clearly showed that both active and passive smokers have a higher risk of breast cancer development and mortality related to this disease compared to non-smokers [16-18]. On the other hand, it has been pointed out that cigarette smoking enhances cell invasion and metastatic development of different types of cancer by the initiation of epithelial-mesenchymal transition (EMT) [19-21], which is the hallmark of cancer progression [22]. Thus, it is evident that tobacco smoking can play an important role in the development and progression of several human carcinomas including breast. However, the impact of WPS on breast carcinogenesis has not been investigated yet. Therefore, in this study, we explored, for the first time, the outcome of WPS on breast cancer progression. Our data show that WPS can induce EMT and stimulate cell invasion of human breast cancer cells via the deregulation of several key controller genes of cancer invasion and metastasis. Thus, we believe that more, in vitro and in vivo, investigations are necessary to elucidate the outcome of WPS in breast cancer progression.

\section{Materials and methods}

\section{Smoking machine protocol and WPS preparation}

A standard smoking protocol (Aleppo Method) was used as described previously by our group [23]. The water pipe was prepared by padding the head with $10 \mathrm{gr}$ of brand tobacco mixture known as "Two Apples", covering it with aluminum foil and perforating the foil to allow air passage. A charcoal, "Three Kings" brand quick-light briquette, was ignited and placed on top of the head at the beginning of the smoking session. Water in the water bowl was changed at the beginning of every smoking session. The condensate (smoking) was collected using regular laboratory filter paper. Filters were dried and weighed before and after collecting smoke and drying. Afterwards, smoked-filters were solved in PBS or RPMI medium (Qiagen, Toronto, ON) with final concertation of $20 \mathrm{mg} / \mathrm{ml}$ of smoking particles; then PBS and RPMI solutions were filtered using $0.45 \mu \mathrm{m}$ (Costar, USA).

\section{Cell lines}

Two human breast cancer cell lines, MCF7 and BT20, were used in our investigation. Cell lines were obtained from the American Type Culture Collection (Rockville, MD, USA) and maintained in a humidified atmosphere of $5 \% \mathrm{CO}_{2}$ in air at $37^{\circ} \mathrm{C}$. The cells were routinely cultured in RPMI 1640 supplemented with $10 \%$ fetal bovine serum (Life Technologies, Inc., ON, Canada), $2 \mathrm{mM}$ L-glutamine, and $100 \mu \mathrm{g} / \mathrm{ml}$ penicillin-streptomycin. Cancer cells were treated with 100 and $200 \mu \mathrm{g} /$ $\mathrm{ml}$ PBS or RPMI solution of WPS; in parallel, control cells were exposed to the same volume of PBS or RPMI serum free.

\section{Invasion assay}

Cell invasion was assayed in 24-well Biocoat Matrigel invasion chambers $(8 \mu \mathrm{m}$; Becton-Dickinson, ON, Canada) according to the manufacturer's protocol. Briefly, cells were incubated with $200 \mu \mathrm{g}$ of WPS solution, and their control $\left(5 \times 10^{4}\right)$ were plated without WPS solution. Both groups were seeded in the top chamber of Biocoat Matrigel wells. The bottom chamber contained RPMI medium with $10 \%$ serum. After 24 -h incubation noninvasive cells were removed with a cotton swab while cells that migrated through the membrane and stuck to the lower surface of the membrane were fixed with methanol and stained with $0.5 \%$ crystal violet. For quantification, cells were counted under a microscope as previously illustrated by our group [24].

\section{Clonogenic cell assay}

Five hundred cells of MCF7 and BT20 were plated in 6-well plates in duplicates. Cells were washed and fresh medium was added in the presence or absence of $200 \mu \mathrm{g}$ of WPS solution. The experiment was discontinued when the clones reached 50 cells/clone in each well ( 7 days), then colonies were fixed and stained with $1.5 \mathrm{ml}$ of $6.0 \%$ glutaraldehyde and $0.5 \%$ crystal violet. Next, colonies were counted using GelCount (Oxford optronix, UK). The colony fraction (CF) of cells was calculated as previously described [25].

\section{Western blot analysis}

MCF7 and BT20 cells were treated with $200 \mu \mathrm{g} / \mathrm{ml}$ of WPS solution in PBS or serum free RPMI for 3 days, as described above. Afterwards, western blot was performed as previously described by our group [26]. Briefly, $30 \mu \mathrm{g}$ of protein from each sample was used in this assay. Protein samples were then blotted on a nitrocellulose membrane and detected with anti-E-cadherin and FAK monoclonal antibodies (mAbs) (Bio/Can Scientific), and 
anti-Erk1/Erk2 phosphotyrosine mAb (Upstate Biotechnology, NY, USA).

\section{Statistical analysis}

Data analyses were performed using SPSS 64-bit version 23 (IBM, NY, USA). Normality of data was confirmed using Shapiro-Wilk test and histograms. Data were analyzed using T-test to determine statistical significance. All tests were two-tailed and results were considered statistically significant if $P$-values were less than 0.05 .

\section{Results}

In order to study the effect of WPS on human breast carcinogenesis, we examined the outcome of WPS on two non- invasive breast cancer cell lines, MCF7 and BT20. Our data revealed that treatment of human breast cancer cells with $100-200 \mu \mathrm{g} / \mathrm{ml}$ of WPS solution for 3 and 8 days slightly deregulates cell cycle progression and increases colony formation, respectively, of MCF7 and BT20 cell lines in comparison with untreated cells (data not shown; Fig. 1). On the other hand, we found that WPS-exposure induces EMT, where both MCF7 and BT20 cells display a more mesenchymal phenotype, and form disorganized multilayered cells in comparison with their matched unexposed controls (Fig. 2). The cells become more elongated in appearance, and show a decrease in cell-cell contact compared with untreated ones.

To evaluate the role of WPS on cell invasion and migration abilities of human breast cancer cells, matrigel invasion and wound-healing assays were performed. In these experiments, MCF7 and BT20 cells were treated for $48 \mathrm{~h}$

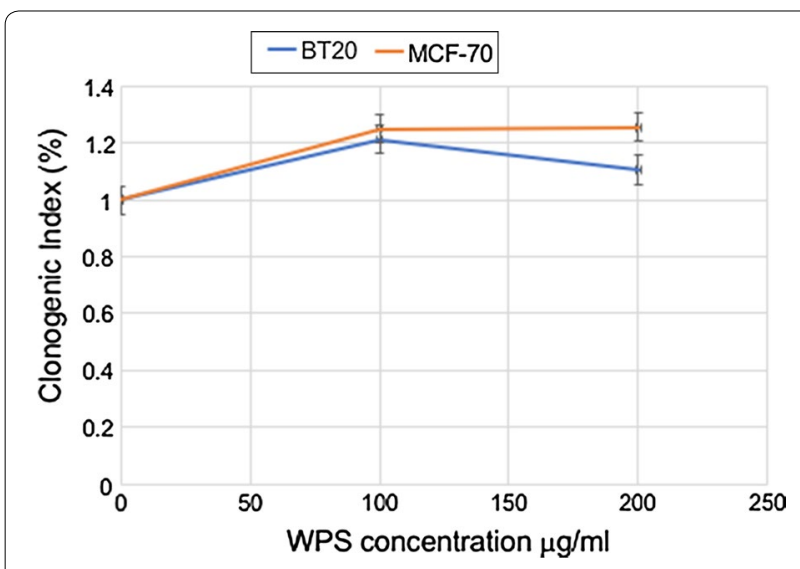

Fig. 1 Effects of water-pipe smoking (WPS) on colony formation in human breast cancer cell lines. WPS slightly enhances colony formation of MCF7 and BT20 cell lines in comparison with their control cells. Clonogenic cell assay and WPS exposure were performed as described in "Materials and methods" section with $200 \mu \mathrm{g} / \mathrm{ml}$ of WPS solution. We found that WPS stimulates cell invasion and migration abilities of both cell lines in comparison with their unexposed controls (Fig. 3). Next, we examined the differential expression patterns of E-cadherin and FAK by Western blot analysis of MCF7 and BT20 cells that were either exposed to $200 \mu \mathrm{g} / \mathrm{ml}$ of WPS for approximately $48 \mathrm{~h}$ or left unexposed. The results of this analysis were consistently correlated with cell phenotype as well as the invasion and migration ability of both cell lines. Following WPS exposure, the expression of E-cadherin is down-regulated in comparison with unexposed cells, in contrast, FAK expression is up-regulated in MCF7 and BT20 control cells in comparison with WPS-exposed ones, which is consistent with EMT progression (dedifferentiation to mesenchymal phenotype) (Figs. 4, 5). In contrast, unexposed cells show a higher and a lower expression of E-cadherin and FAK, respectively, which is also coherent with EMT progression that enhances cell migration and invasion abilities.

Regarding the mechanisms of WPS on the initiation of EMT and therefore cell invasion in human breast cancer cells, we assumed that the main mechanism behind these events could be Erk1/Erk2 signaling pathways, since it has been reported that tobacco smoking can provoke EMT via Erk1/Erk2 pathways [19, 21]. Thus, Erk1/ Erk2 activation was assessed in MCF7 and BT20 cell lines exposed to WPS in comparison with their matched control cells. We found that Erk1/Erk2 is phosphorylated under the effect of WPS, in both cell lines in comparison with their control (Figs. 4, 5). Meanwhile, we noted that there is no significant difference in total Erk1/Erk2 expression between WPS exposed and control cells (data not shown).

\section{Discussion}

In this investigation, we explored for the first time the outcome of WPS on breast carcinogenesis. Indeed, the effect of WPS on breast cancer initiation and/or progression has not been explored yet. Our study revealed that WPS can initiate the EMT event in human breast cancer cells, which is the hallmark of cancer progression and metastasis [22]. Moreover, our data show clearly that WPS stimulate cell invasion of human breast cancer cells. While, numerous recent investigations have demonstrated a strong association between tobacco smoking and breast cancer development and progression in addition to recurrence and mortality [15, 27-29]. Also, it has been revealed that cigarette smoking can enhance EMT of several human carcinoma cells including breast [19, 30-33]. Additionally, earlier studies showed that cigarette smoking could increase breast cancer recurrence by $37 \%$, and therefore increase the overall mortality by $54 \%$ compared 

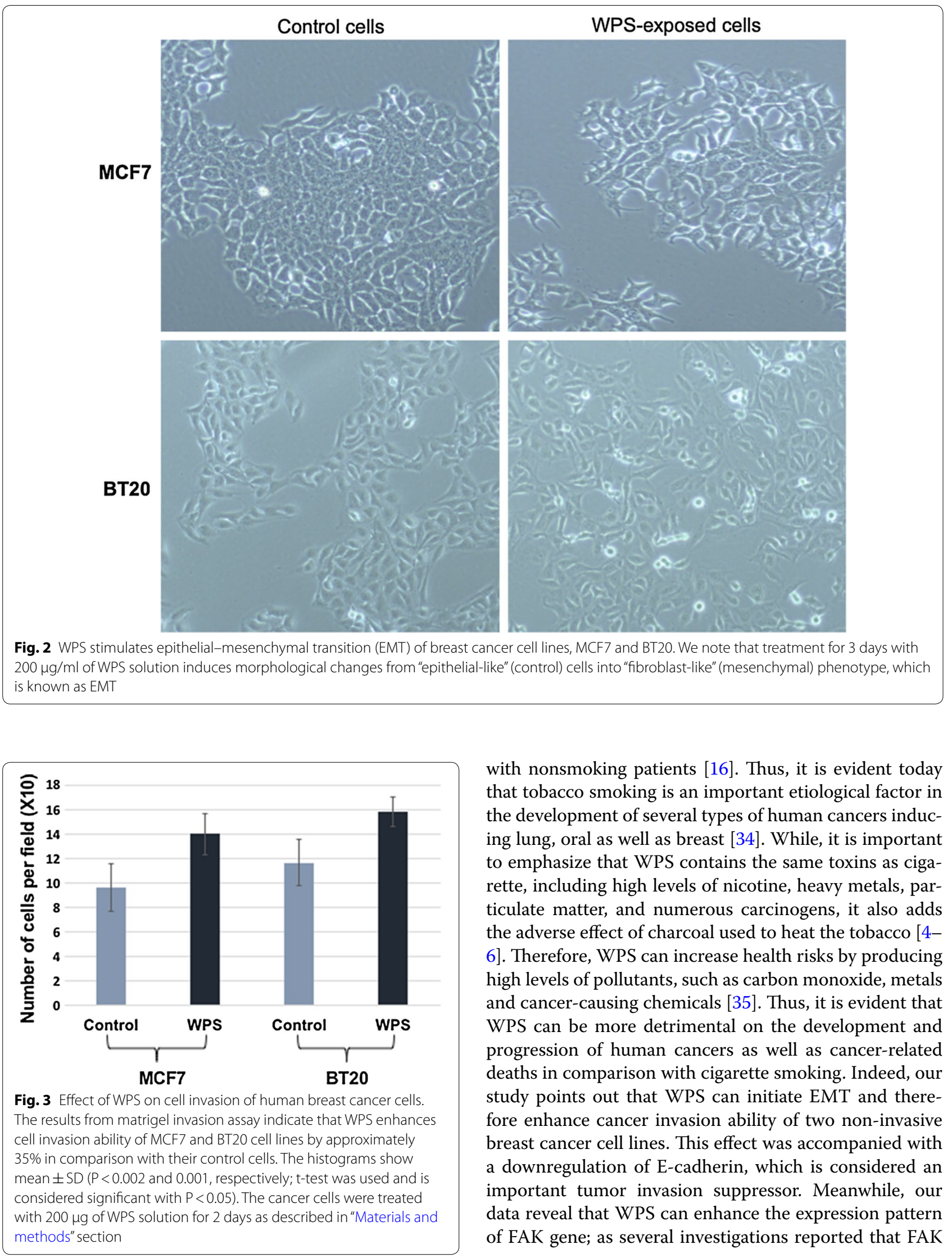

with nonsmoking patients [16]. Thus, it is evident today that tobacco smoking is an important etiological factor in the development of several types of human cancers inducing lung, oral as well as breast [34]. While, it is important to emphasize that WPS contains the same toxins as cigarette, including high levels of nicotine, heavy metals, particulate matter, and numerous carcinogens, it also adds the adverse effect of charcoal used to heat the tobacco [46]. Therefore, WPS can increase health risks by producing high levels of pollutants, such as carbon monoxide, metals and cancer-causing chemicals [35]. Thus, it is evident that WPS can be more detrimental on the development and progression of human cancers as well as cancer-related deaths in comparison with cigarette smoking. Indeed, our study points out that WPS can initiate EMT and therefore enhance cancer invasion ability of two non-invasive breast cancer cell lines. This effect was accompanied with a downregulation of E-cadherin, which is considered an important tumor invasion suppressor. Meanwhile, our data reveal that WPS can enhance the expression pattern of FAK gene; as several investigations reported that FAK 


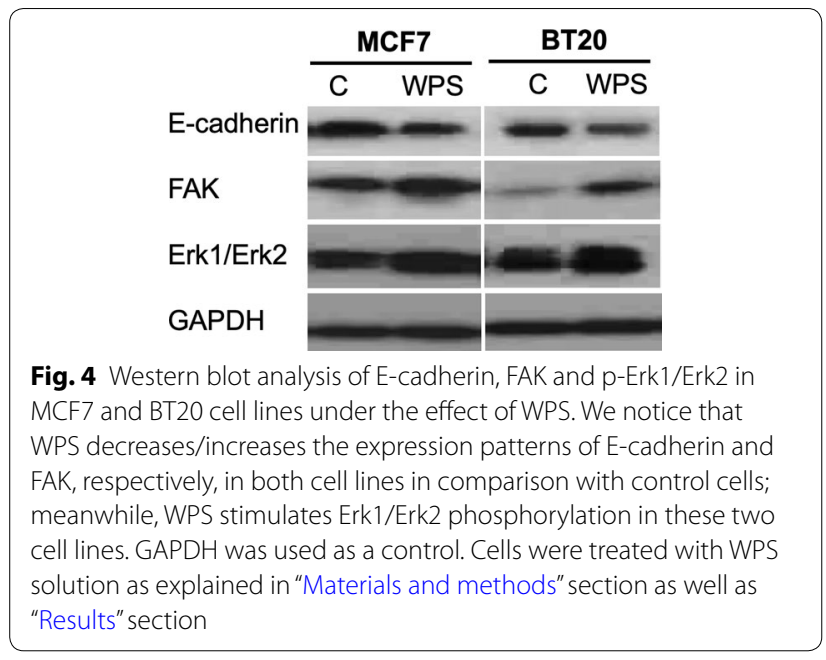

is an important key controller gene of cell invasion and metastasis in several types of human carcinomas including breast. Thus, our data concur that cigarette smoking can enhance cancer progression via the initiation of EMT, which is accompanied by the deregulation of E-cadherin, and FAK, as it was clearly demonstrated by several investigations [36-40]. On the other hand, we have recently reported that WPS induces an overexpression of cadherin-6 (CDH6) type 2 gene during embryogenesis [23], which is also involved in the normal development and cancer progression via the initiation of EMT [41-43]. Consequently, we assume that WPS can deregulate the expression pattern of $\mathrm{CDH} 6$ type 2 gene in human cancer cells. Taken together, we believe that WPS exposure could have a dramatic effect on the progression of several types of human cancers, including breast, and therefore, cancer mortality.

More significantly, we herein report that WPS activate Erk1/Erk2, which could be the main pathway behind inducing EMT and cell invasion leading to the deregulation of E-cadherin and FAK genes in human breast cancer cells. Herein, it is important to highlight that WPS did not significantly affect the total expression of Erk1/Erk2. Indeed, these data are consistent with previous works regarding cigarette smoking in relation with EMT and Erk1/Erk2 activation, as well as E-cadherin deregulation in various types of human cancer cells including breast [19, 21, 4446]. Thus, the present study show that Erk1/Erk2 activation is one of the pathways via which WPS can enhance cancer progression and initiate metastasis.

\section{Conclusions}

In conclusion, we herein demonstrate for the first time that WPS can enhance cancer invasion ability of human breast cancer via the initiation of EMT, which
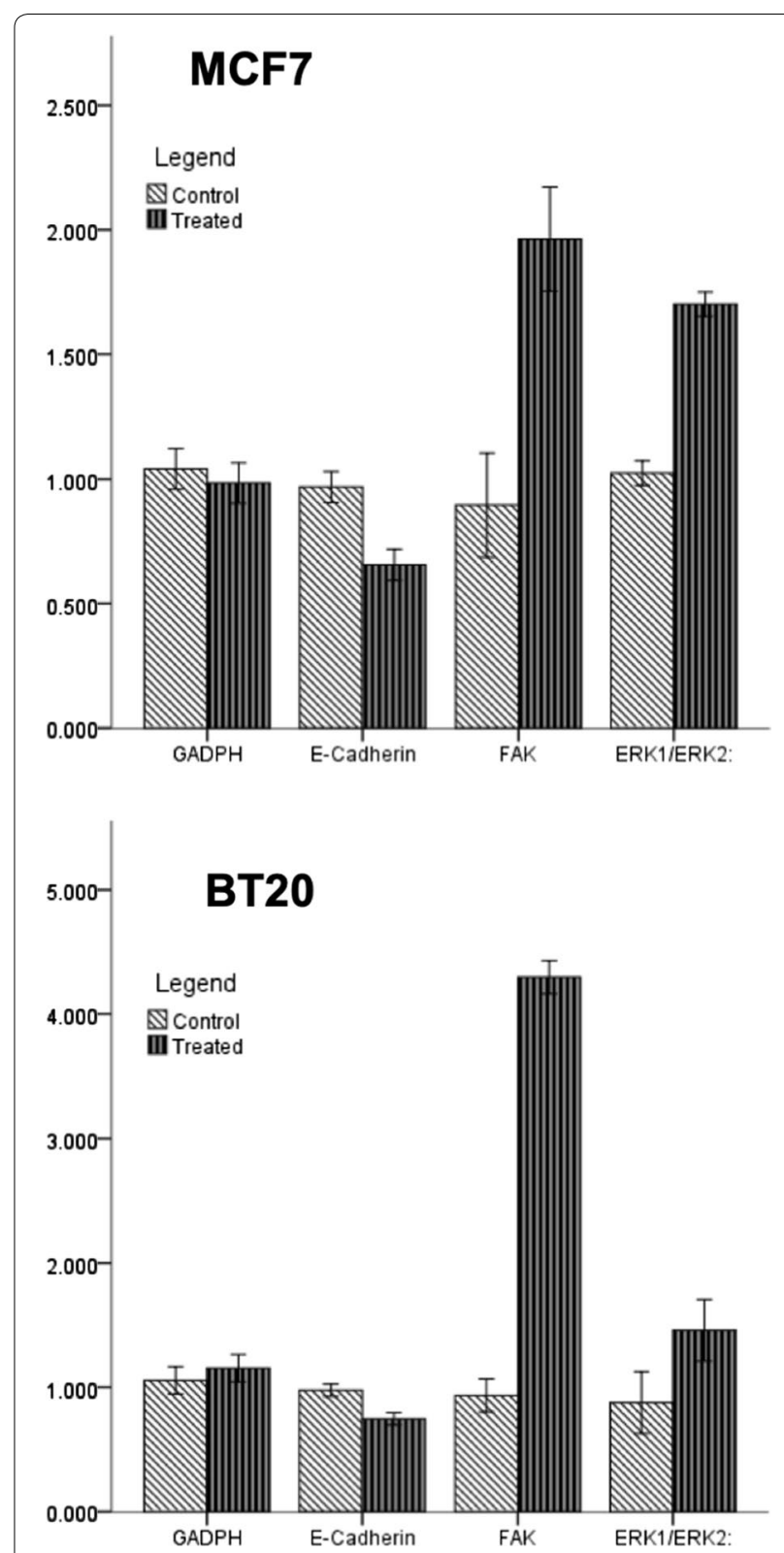

Fig. 5 Quantification of the western blot analysis of E-cadherin, FAK and Erk1/Erk2 phosphorylation as well as GAPDH in MCF7 and BT20 exposed to WPS and unexposed (control) cells. This analysis confirms the downregulation of E-cadherin in both cell lines; in parallel, WPS enhances FAK expression and Erk1/Erk2 phosphorylation in the two cell lines in comparison with their control cells. The quantification of both data by ImageJ 64-bit version 1.50b program

is an important event in cancer progression. In parallel, E-cadherin and FAK genes are major targets of WPS in human breast cancer. Finally, our study reveals that this effect can occur via the activation of Erk1/Erk2 pathways. Therefore, it provides evidence that WPS can play a critical role in the progression of human breast cancer. 
However, further studies are required to elucidate the pathogenic effects of WPS on the development and progression of human carcinomas including breast.

\section{Authors' contributions}

KWS, MYH, AAA and AEA — conceptualization, formal analysis, funding acquisition, experiments, and writing - review and editing. TB, TA, AY, SV and AZ-formal analysis, data curation. All authors (KWS, MYH, AAA, TB, TA, AY, SV, AZ, AEA) —writing —original draft, review and editing. All authors read and approved the final manuscript.

\section{Author details}

${ }^{1}$ College of Medicine, Qatar University, Doha, Qatar. ${ }^{2}$ Biomedical Research Centre, Qatar University, Doha, Qatar. ${ }^{3}$ Segal Cancer Centre, Lady Davis Institute for Medical Research of the Sir Mortimer B. Davis-Jewish General Hospital, Montreal, QC, Canada. ${ }^{4}$ Oncology Department, McGill University, Montreal, QC, Canada. ${ }^{5}$ Syrian Research Cancer Centre of the Syrian Society against Cancer, Aleppo, Syria.

\section{Acknowledgements}

We would like to thank Mrs. A. Kassab for her critical reading of the manuscript.

\section{Competing interests}

The authors declare that they have no competing interests. The sponsor had no role in the design and conduct of the study or in the preparation, review, or approval of the manuscript.

\section{Consent for publication}

Not applicable.

\section{Data availability statement}

The datasets used and analyzed in the current study are available from the corresponding authors on reasonable request.

\section{Ethics approval and consent to participate}

Not applicable.

\section{Funding}

This work was supported by student Grant\# QUST-1-CMED-2018-2 from Qatar University. The publication of this article was funded by the Qatar National Library

\section{Publisher's Note}

Springer Nature remains neutral with regard to jurisdictional claims in published maps and institutional affiliations.

Received: 11 October 2018 Accepted: 6 November 2018

Published online: 13 November 2018

\section{References}

1. Maziak W. The global epidemic of waterpipe smoking. Addict Behav. 2011;36(1-2):1-5

2. Maziak W, Taleb ZB, Bahelah R, Islam F, Jaber R, Auf R, et al. The global epidemiology of waterpipe smoking. Tob Control. 2015;24(Suppl 1):i3-12.

3. Maziak W, Ben Taleb Z, Jawad M, Afifi R, Nakkash R, Akl EA, et al. Consensus statement on assessment of waterpipe smoking in epidemiological studies. Tob Control. 2017;26(3):338-43.

4. Boskabady MH, Farhang L, Mahmodinia M, Boskabady M, Heydari GR. Comparison of pulmonary function and respiratory symptoms in water pipe and cigarette smokers. Respirology. 2012;17(6):950-6.

5. Jacob P 3rd, Abu Raddaha AH, Dempsey D, Havel C, Peng M, Yu L, et al. Comparison of nicotine and carcinogen exposure with water pipe and cigarette smoking. Cancer Epidemiol Biomarkers Prev. 2013;22(5):765-72.
6. Lopez AA, Eissenberg T, Jaafar M, Afifi R. Now is the time to advocate for interventions designed specifically to prevent and control waterpipe tobacco smoking. Addict Behav. 2017;66:41-7.

7. Raad D, Gaddam S, Schunemann HJ, Irani J, Abou Jaoude P, Honeine R, et al. Effects of water-pipe smoking on lung function: a systematic review and meta-analysis. Chest. 2011;139(4):764-74.

8. Montazeri Z, Nyiraneza C, El-Katerji H, Little J. Waterpipe smoking and cancer: systematic review and meta-analysis. Tob Control. 2017;26(1):92-7.

9. Bentur L, Hellou E, Goldbart A, Pillar G, Monovich E, Salameh M, et al. Laboratory and clinical acute effects of active and passive indoor group water-pipe (narghile) smoking. Chest. 2014;145(4):803-9.

10. Juhasz A, Pap D, Barta I, Drozdovszky O, Egresi A, Antus B. Kinetics of exhaled carbon monoxide after water-pipe smoking indoors and outdoors. Chest. 2017;151(5):1051-7.

11. Rastam S, Li FM, Fouad FM, Al Kamal HM, Akil N, Al Moustafa AE. Water pipe smoking and human oral cancers. Med Hypotheses. 2010;74(3):457-9.

12. Rojewski AM, Baldassarri S, Cooperman NA, Gritz ER, Leone FT, Piper ME, et al. Exploring issues of comorbid conditions in people who smoke. Nicotine Tob Res. 2016;18(8):1684-96.

13. Sauer AG, Siegel RL, Jemal A, Fedewa SA. Updated review of prevalence of major risk factors and use of screening tests for cancer in the United States. Cancer Epidemiol Biomarkers Prev. 2017;26(8):1192-208.

14. Inoue-Choi M, Hartge P, Liao LM, Caporaso N, Freedman ND. Association between long-term low-intensity cigarette smoking and incidence of smoking-related cancer in the national institutes of health-AARP cohort. Int J Cancer. 2018;142(2):271-80.

15. Andersen ZJ, Jorgensen JT, Gron R, Brauner EV, Lynge E. Active smoking and risk of breast cancer in a Danish nurse cohort study. BMC Cancer. 2017;17(1):556

16. Pierce JP, Patterson RE, Senger CM, Flatt SW, Caan BJ, Natarajan L, et al. Lifetime cigarette smoking and breast cancer prognosis in the After Breast Cancer Pooling Project. J Natl Cancer Inst. 2014;106(1):359.

17. Macacu A, Autier P, Boniol M, Boyle P. Active and passive smoking and risk of breast cancer: a meta-analysis. Breast Cancer Res Treat. 2015;154(2):213-24.

18. Sollie M, Bille C. Smoking and mortality in women diagnosed with breast cancer-a systematic review with meta-analysis based on 400,944 breast cancer cases. Gland Surg. 2017;6(4):385-93.

19. Sun X, Deng Q, Liang Z, Liu Z, Geng H, Zhao L, et al. Cigarette smoke extract induces epithelial-mesenchymal transition of human bladder cancer T24 cells through activation of ERK1/2 pathway. Biomed Pharmacother. 2017:86:457-65.

20. Jeon SY, Go RE, Heo JR, Kim CW, Hwang KA, Choi KC. Effects of cigarette smoke extracts on the progression and metastasis of human ovarian cancer cells via regulating epithelial-mesenchymal transition. Reprod Toxicol. 2016;65:1-10

21. Yu D, Geng H, Liu Z, Zhao L, Liang Z, Zhang Z, et al. Cigarette smoke induced urocystic epithelial mesenchymal transition via MAPK pathways. Oncotarget. 2017;8(5):8791-800.

22. Al Moustafa AE, Achkhar A, Yasmeen A. EGF-receptor signaling and epithelial-mesenchymal transition in human carcinomas. Front Biosci. 2012;4:671-84.

23. Ashour AA, Haik MY, Sadek KW, Yalcin HC, Bitharas J, Aboulkassim T, et al. Substantial toxic effect of water-pipe smoking on the early stage of embryonic development. Nicotine Tob Res. 2018;20(4):502-7.

24. Yasmeen A, Alachkar A, Dekhil H, Gambacorti-Passerini C, Al Moustafa AE. Locking Src/Abl tyrosine kinase activities regulate cell differentiation and invasion of human cervical cancer cells expressing E6/E7 oncoproteins of high-risk HPV. J Oncol. 2010;2010. pii:530130

25. Franken NA, Rodermond HM, Stap J, Haveman J, van Bree C. Clonogenic assay of cells in vitro. Nat Protoc. 2006;1(5):2315-9.

26. Saleh Al, Mohamed I, Mohamed AA, Abdelkader M, Yalcin HC, Aboulkas$\operatorname{sim} T$, et al. Elaeagnus angustifolia plant extract inhibits angiogenesis and downgrades cell invasion of human oral cancer cells via Erk1/Erk2 inactivation. Nutr Cancer. 2018;70(2):297-305.

27. White AJ, D'Aloisio AA, Nichols HB, DeRoo LA, Sandler DP. Breast cancer and exposure to tobacco smoke during potential windows of susceptibility. Cancer Causes Control. 2017;28(7):667-75. 
28. Strumylaite L, Kregzdyte R, Poskiene L, Bogusevicius A, Pranys D, Norkute R. Association between lifetime exposure to passive smoking and risk of breast cancer subtypes defined by hormone receptor status among nonsmoking Caucasian women. PLoS ONE. 2017;12(2):e0171198.

29. Mele A, Mehta P, Slanetz PJ, Brook A, Recht A, Sharma R. Breast-conserving surgery alone for ductal carcinoma in situ: factors associated with increased risk of local recurrence. Ann Surg Oncol. 2017;24(5):1221-6.

30. Pillai S, Trevino J, Rawal B, Singh S, Kovacs M, Li X, et al. Beta-arrestin-1 mediates nicotine-induced metastasis through E2F1 target genes that modulate epithelial-mesenchymal transition. Can Res. 2015;75(6):1009-20.

31. Liu Y, Luo F, Xu Y, Wang B, Zhao Y, Xu W, et al. Epithelial-mesenchymal transition and cancer stem cells, mediated by a long non-coding RNA, HOTAIR, are involved in cell malignant transformation induced by cigarette smoke extract. Toxicol Appl Pharmacol. 2015;282(1):9-19.

32. Dinicola S, Masiello MG, Proietti S, Coluccia P, Fabrizi G, Catizone A, et al. Nicotine increases colon cancer cell migration and invasion through epithelial to mesenchymal transition (EMT): COX-2 involvement. J Cell Physiol. 2018;233(6):4935-48.

33. Chen PC, Lee WY, Ling HH, Cheng $\mathrm{CH}$, Chen $\mathrm{KC}$, Lin CW. Activation of fibroblasts by nicotine promotes the epithelial-mesenchymal transition and motility of breast cancer cells. J Cell Physiol. 2018;233(6):4972-80.

34. Lee PN, Thornton AJ, Hamling JS. Epidemiological evidence on environmental tobacco smoke and cancers other than lung or breast. Regul Toxicol Pharmacol. 2016:80:134-63.

35. Kim KH, Kabir E, Jahan SA. Waterpipe tobacco smoking and its human health impacts. J Hazard Mater. 2016;317:229-36.

36. Nagathihalli NS, Massion PP, Gonzalez AL, Lu P, Datta PK. Smoking induces epithelial-to-mesenchymal transition in non-small cell lung cancer through HDAC-mediated downregulation of E-cadherin. Mol Cancer Ther. 2012;11(11):2362-72.

37. Li D, Zhang L, Zhou J, Chen H. Cigarette smoke extract exposure induces EGFR-TKI resistance in EGFR-mutated NSCLC via mediating Src activation and EMT. Lung Cancer. 2016;93:35-42.
38. Kim CW, Lee HM, Lee K, Kim B, Lee MY, Choi KC. Effects of cigarette smoke extracts on cell cycle, cell migration and endocrine activity in human placental cells. Reprod Toxicol. 2017;73:8-19.

39. Momi N, Ponnusamy MP, Kaur S, Rachagani S, Kunigal SS, Chellappan $\mathrm{S}$, et al. Nicotine/cigarette smoke promotes metastasis of pancreatic cancer through alpha7nAChR-mediated MUC4 upregulation. Oncogene. 2013;32(11):1384-95.

40. Park GB, Kim D. Cigarette smoke-induced EGFR activation promotes epithelial mesenchymal migration of human retinal pigment epithelial cells through regulation of the FAK-mediated Syk/Src pathway. Mol Med Rep. 2018;17(3):3563-74.

41. Clay MR, Halloran MC. Cadherin 6 promotes neural crest cell detachment via F-actin regulation and influences active Rho distribution during epithelial-to-mesenchymal transition. Development. 2014;141(12):2506-15.

42. Gugnoni M, Sancisi V, Gandolfi G, Manzotti G, Ragazzi M, Giordano D, et al. Cadherin- 6 promotes EMT and cancer metastasis by restraining autophagy. Oncogene. 2017;36(5):667-77.

43. Zuo LL, Zhang J, Liu LZ, Zhou Q, Du SJ, Xin SY, et al. Cadherin 6 is activated by Epstein-Barr virus LMP1 to mediate EMT and metastasis as an interplay node of multiple pathways in nasopharyngeal carcinoma. Oncogenesis. 2017;6(12):402.

44. Chen QW, Edvinsson L, Xu CB. Cigarette smoke extract promotes human vascular smooth muscle cell proliferation and survival through ERK1/2and NF-kappaB-dependent pathways. Sci World J. 2010;10:2139-56.

45. Liu M, Zhou C, Zheng J. Cigarette smoking impairs the response of EGFR-TKIs therapy in lung adenocarcinoma patients by promoting EGFR signaling and epithelial-mesenchymal transition. Am J Transl Res. 2015;7(10):2026-35.

46. Chen ZB, Liu C, Chen FQ, Li SY, Liang Q, Liu LY. Effects of tobacco-specific carcinogen 4-(methylnitrosamino)-1-(3-pyridyl)-1-butanone (NNK) on the activation of ERK1/2 MAP kinases and the proliferation of human mammary epithelial cells. Environ Toxicol Pharmacol. 2006;22(3):283-91.
Ready to submit your research? Choose BMC and benefit from:

- fast, convenient online submission

- thorough peer review by experienced researchers in your field

- rapid publication on acceptance

- support for research data, including large and complex data types

- gold Open Access which fosters wider collaboration and increased citations

- maximum visibility for your research: over 100M website views per year

At BMC, research is always in progress.

Learn more biomedcentral.com/submissions 